\title{
Elements of satisfactory online asynchronous teacher behaviour in higher education
}

\author{
Anneke Smits \\ Windesheim University \\ Joke Voogt \\ University of Amsterdam/Windesheim University
}

\begin{abstract}
In this study, differences were analysed between two groups of online teachers in a Master of Special Educational Needs program. One group scored high on student satisfaction and the second group received low student satisfaction ratings. Findings indicate that high satisfaction is associated with relatively long and pedagogically complex messages that are most often addressed to the whole group. These messages are characterised by careful listening to the students, elaborate on content knowledge, and show online personality and social behaviour. The research resulted in preliminary guidelines for crafting asynchronous teacher messages that positively affect student satisfaction and a scoring guideline that can be used to score the quality of online teaching as expressed in online asynchronous messages.
\end{abstract}

\section{Introduction}

In this age of blended learning, e-learning and MOOCs, the number of teachers transitioning to teaching online is increasing steadily. However, this transition is far from self-evident (Conrad, 2004; Reilly, Vandenhouten, Gallagher-Lepak, \& Ralston-Berg, 2012; Shattuck \& Anderson, 2013) as online teaching behaviour differs from face-to-face teaching behaviour (Conceição, 2006; Coppola, Hiltz, \& Rotter, 2002; Easton, 2003) and online teachers often lack insight in online teaching processes and procedures (Abdous, 2010). Detailed, empirically based guidelines of effective online teaching behaviour for beginning and practising online teachers are lacking. Much of the rather complex advice in the literature is anecdotal rather than empirical in nature. There is an expanding body of research on online teaching roles (see the review of Baran, Correia, \& Thompson, 2011), but these are most often described as rather abstract conceptualisations that miss the practicality that teachers need to transform their daily practice. Fear and resistance to online teaching may arise from the lack of clear and practical guidelines (Abdous, 2010; Shattuck \& Anderson, 2013).

Online education is not without problems. Dissatisfied students and elevated dropout rates are no exception, and online collaborative knowledge construction does not come about easily (Kreijns, 2004; Lee \& Choi, 2010). Skilled online teachers are critically important to online education. Online student-teacher interaction positively influences student satisfaction (Sher, 2009), and student learning (Arbaugh, 2014; Marks, Sibley, \& Arbaugh, 2005; Mullen \& Tallent-Runnels, 2006) reduces transactional distance (Arbaugh \& Hwang, 2006; Stein, Wanstreet, Calvin, Overtoom, \& Wheaton, 2005) and may prevent attrition (Levy, 2007). However, the quality of teacher participation in online learning is not self-evident, and continuing development of online teaching skills is needed as practising teachers differ greatly in teaching style and teaching effectiveness (Baran, Correia, \& Thompson, 2011, 2013; Morris, Xu, \& Finnegan, 2005).

The literature shows consensus on the subject of online teaching roles, although the terms that are used may differ somewhat between authors. In a review of the literature, Baran et al. (2011) found that the following online teaching roles are repeatedly mentioned: pedagogical, facilitator, instructional designer, social, managerial and technical. Each of these roles consists of multiple behavioural elements, that is, a set of different concrete behavioural manifestations of the teaching role. Several studies endeavoured to conduct a qualitative analysis of the concrete behavioural elements of online teaching in order to put flesh on the bones of the teaching roles and help online teachers to understand what pedagogical behaviour is expected of them (Anderson, Rourke, Garrison, \& Archer, 2001; Blignaut \& Trollip, 2003; Morris et al., 2005, Nandi, 
Hamilton, \& Harland, 2012). The behavioural descriptions resulting from these studies are complex and show large differences among online teachers. Blignaut and Trollip (2003) state in their discussion that however useful this type of qualitative analysis is in itself, the next step should be to correlate the different teaching behaviours with learning outcomes and student satisfaction. In this study, we will pursue this question with regard to satisfaction. Establishing links between behavioural elements and student satisfaction clarifies which pedagogical behaviours should be prioritised in order to positively affect student satisfaction. Several studies have shown relationships between student satisfaction and different aspects of teaching roles on the basis of student surveys (e.g., Arbaugh, 2001, 2014). To our knowledge, there is no study to date that entails both the quantitative and qualitative analyses of the online behaviour of groups of teachers in relation to student satisfaction.

Online teaching roles can be fulfilled through different means of communication: synchronous and asynchronous, spoken and written. This study focuses on an e-learning design with asynchronously written messages as the primary form of communication in the learning environment (see Smits, Voogt, \& van den Akker, 2013). In asynchronous online learning, pedagogical behaviour materialises in the wording of the teachers' asynchronous messages. The question relevant for online teachers is how to craft these online messages in such a way that the different teaching roles are adequately expressed and lead to student satisfaction and learning. This question led to the current study, which entails the quantitative and qualitative analysis of behavioural elements in asynchronous teacher messages and the analysis of the teaching behaviour of two different groups of online teachers: one group with high student satisfaction (HS) and one group with low student satisfaction (LS).

\section{Context}

This study took place in the online Master of Special Educational Needs (MSEN) diploma course in an institute for higher education in the Netherlands. The MSEN is a two-year, part-time online diploma course with a study load of 20 study hours per week. In the program, specialised teacher competencies are developed. Knowledge, skills and professional beliefs are integrated objectives of the program. Students learn to solve complex authentic problems in professional practice on the basis of knowledge and research outcomes. The online program attracts 40-50 students each year. Most students are female and work as teachers in primary education.

The MSEN was designed through a design-based research project that took place between 2005 and 2009 (Smits, 2012; Smits et al., 2013). The central research problem of this design-based project was to translate the existing face-to-face course to a fully online course. Major design concerns were usability for teachers and students and student satisfaction and effect in terms of academic success. The course design was based on an extensive study of the literature, which resulted in four clusters of design principles: interaction among students, structure, the teacher's role and course materials (Smits et al., 2013). In successive research phases, the principles were refined and validated. Asynchronous teaching discussion, teacher moderation and the asynchronous café are at the heart of the design. Students participate in asynchronous teaching discussions in small groups of 4-8 students. Adequate participation in discussions is required before students get permission to hand their final individual paper. Students are required to post at least 2 or 3 times per week. The participation requirements are clarified for students through the use of rubrics based on Pallof and Pratt (2003). The rubrics concern the use of course content and literature, application of theory in practice, active listening and responding to others, quality of language use and APA style. No grades are assigned to the postings. All teaching discussions are teacher moderated. When necessary (mostly in the students' first elearning course) teachers provide individual feedback on the quality of the students' postings on the basis of the rubrics. Normally, most communication takes place within the group. Individual communication between teacher and student does occur but is kept to a minimum in order to constrain teacher workloads. The asynchronous café is the place for off-topic conversations and organisational matters within the small group.

The design research project resulted in six design principles for the teachers' role regarding presence, moderation, feedback, organisation, social presence and monitoring/activation. The presence principle means 
that teachers manifest themselves visibly in the online environment at least three times per week through written contributions to the asynchronous discussions. Much less frequently and on the basis of specific needs, teachers and students seek contact through synchronous means of communication, mostly telephone or Skype. The moderation principle entails that the teacher moderates the discussion based on both communicative competencies and a deep understanding of the academic content in order to focus the discussions and to facilitate student learning. Students are provided with acknowledgement, encouragement and specific feedback. In this type of feedback, accurate descriptions are more important than value labels (Faber \& Mazlish, 1996; Nicol \& Milligan, 2006). The feedback departs from a description of positive points in the work of the students after which points for improvement may be introduced when necessary. Organisational support by the teacher is seen as clarifying organisational matters such as assignments, expectations, assessment and technology. Organisational questions are primarily answered in the asynchronous café. For personal matters, email is used. Teacher social presence means that teachers show their online personality through social and emotional communicative behaviours meant to reduce the psychological distance and to increase the sense of mutual safety. Through affective behaviour, the teacher sets the tone for the atmosphere in the group. The teacher also prevents and regulates negative behaviour that may arise in groups. Social presence of the teacher does not only have affective goals, but also cognitive goals: to create an enjoyable and fruitful ground for higher-order thinking processes that evokes engagement and leads to intrinsic motivation and persistence (Rourke, Anderson, Garrison, \& Archer, 1999).

The six design principles for the teachers' role are important factors in creating a rich and satisfactory online learning environment for students. However, formulating and clarifying design principles differs from actually enacting them as a teacher. Without behavioural analysis and data on students' appreciation of the enacted teaching role, it is not clear whether teachers really live up to these complex behavioural requirements. The question also remains whether all of these behavioural aspects are equally important for students. To answer these questions, this study aims to identify elements of teacher behaviour in asynchronous messages as well as the differences between the messages of two groups of online teachers: one group that generates high student satisfaction (HS) and one group that generates low student satisfaction (LS). Research questions are:

- Which elements of teaching behaviour can be identified in asynchronous teacher messages?

- Which differences in behavioural elements can be identified between the HS and LS teacher groups?

- How do the number of messages and the complexity of messages differ between HS and LS teachers?

\section{Dilemmas in the online teaching role}

The literature does not agree on the frequency, the depth and the nature of the activities that online teachers need to show (Nandi et al., 2012). Some adhere to the 'silence is golden, ghost in the wings or sit on hands' principle, where teachers do watch over the discussion but hardly contribute any messages themselves (Mazzolini \& Maddison, 2003; Rourke \& Anderson, 2002). The goal of this instructor inactivity is to give students ample opportunity and freedom to create their own discussion (Brower, 2003). Such freedom may be feasible with highly knowledgeable students but, in general, it seems a minority point of view as it may lead to risks such as student passivity, loss of motivation, loss of goal orientation and suboptimal learning in discussions (Conrad, 2005; Hewitt, 2005; Savery, 2005). Many authors contend that instructors are critical for student engagement and learning in asynchronous discussion (Arbaugh, 2010; Blignaut \& Trollip, 2003; Ferdig \& Roehler, 2004; Roblyer \& Wiencke, 2003); although, at the same time, there is not enough research to create consensus on the optimal behaviours for online instructors in asynchronous discussions (Blignaut \& Trollip, 2003; Nandi et al., 2012). Most studies concern the teaching role as such, without a breakdown of the teaching role in constituting behaviours. Therefore, gaps exist in our current understanding of the online teaching role.

A second dilemma is whether a separate role for the online teacher needs to exist in online learning. The online teaching role gained momentum with the seminal article on the community of inquiry framework (CoI) 
of Garrison, Anderson, and Archer in 2000. In their article, the authors conceptualised the teaching role as one of three roles: social, cognitive and teaching. They proposed an egalitarian CoI in which students and teachers enact all three roles. Despite all efforts to validate the CoI framework (see Rourke and Kanuka, 2009 for a list of studies), it has been under some scrutiny. Shea et al. (2014) wonder how realistic the CoI framework is in the context of higher education, where teachers and students have very different objectives that lead to very different roles. In their study, students, even when explicitly assigned facilitating roles, did not display this teaching role very often, and when they did, this did not bring them into the centre of attention of the other students. They conclude that teachers cannot rest assured in role-sharing with students, but have their own roles to play: "These roles include, but are not limited to: principal guide, coach, and instructional designer, recognised provider of limited but crucial direct instruction, lead supporter of meta-cognition, and ultimate arbiter of 'official' evaluation” (Shea et al., 2014, p. 14).

The third dilemma pertains to the workload of online teachers. Adhering to the 'silence is golden' principle has the advantage of minimising the workload of online teachers who may read the student messages, but hardly compose any messages themselves. A more active and complex teaching role, with timely, frequent and complex written messages, leads to the perception of a high workload (Bolliger \& Wasilik, 2009; Conrad, 2004; Dunlap, 2005; Huang \& Hsiao, 2012; Smits, 2012; Spector, 2005). Insufficient compensation for this workload inhibits teachers to adequately moderate online discussions (Ke, 2010) and, even worse, proves to be a primary demotivator for teaching online (Shea, 2007). When administrators are not convinced of the effects of online teaching, then adequate compensation may well be found lacking. Research into the importance of quantitative and qualitative aspects of teacher messages may, in the end, provide the fertile ground that is needed to adequately fund online teaching efforts.

\section{Online teacher behaviours}

The teaching roles that have been described in the literature are rather abstract entities that do not disclose the full range of teaching behaviours and their relative importance and, as such, may be of little practical value for teachers seeking guidance for their online teaching. Practising and future online teachers, as well as administrators, need concrete behavioural information about the teaching role. A limited number of researchers have taken up this challenge, but the area remains relatively under-researched, especially when it comes to a more detailed description of the behaviour within the teacher role. Two studies (Blignaut \& Trollip, 2003; Nandi et al., 2012) were identified that analysed concrete teaching behaviour in asynchronous discussions through an open coding stance. Table 1 shows information on the two studies.

Table 1

Information on the two research projects

\begin{tabular}{lcccc}
\hline $\begin{array}{c}\text { Authors, year of } \\
\text { publication }\end{array}$ & \multicolumn{1}{c}{ Research context } & $\begin{array}{c}\text { Number of } \\
\text { online } \\
\text { instructors }\end{array}$ & $\begin{array}{c}\text { Number of } \\
\text { teacher } \\
\text { messages }\end{array}$ & $\begin{array}{c}\text { Mean } \\
\text { number of } \\
\text { teacher } \\
\text { messages } \\
\text { per }\end{array}$ \\
$\begin{array}{c}\text { Blignaut \& Trollip } \\
\text { (2003) }\end{array}$ & $\begin{array}{c}9 \text { graduate-level courses }(2 \text { instructors } \\
\text { taught each of these courses in } \\
\text { parallel): Business/Education }\end{array}$ & 18 & 2746 & 10.38 \\
Nandi et al. (2012) & $\begin{array}{c}\text { (under)graduate level courses: } \\
\text { IT/Programming }\end{array}$ & $\begin{array}{c}1 \text { with } 0-3 \\
\text { tutors per } \\
\text { course }\end{array}$ & $\begin{array}{c}\text { Not reported, Not reported } \\
\text { courses } \\
\text { partially } \\
\text { analysed }\end{array}$ \\
\hline
\end{tabular}

At first sight, it is difficult to see relationships between the findings of the two studies because different terminology is used. With the help of the authors' explanations and examples comparable (but not identical) items are clustered in Table 2 in teacher roles that match the behavioural descriptions but may differ in 
terminology from the original teacher role that was identified by the authors. For the Blignaut and Trollip (2003) study, the category 'other' was left out, because no link could be made to a particular teacher role. For the other roles, percentages are reported from the total of messages in each study. For the Nandi et al. (2012) study, these percentages are reported separately for each course.

Table 2

Teacher roles and behaviours in the two research projects

\begin{tabular}{|c|c|c|}
\hline Teacher role & $\begin{array}{c}\text { Percentage of all messages } \\
\text { found in research project(s)* }\end{array}$ & $\begin{array}{c}\text { Teacher behaviour } \\
\text { found in research project(s)* }\end{array}$ \\
\hline $\begin{array}{l}\text { Administrative (without } \\
\text { academic content) }\end{array}$ & $\begin{array}{l}22.1 \%(1) \\
18.6 \%(2 \mathrm{a}) \\
19.6 \%(2 \mathrm{~b})\end{array}$ & $\begin{array}{l}\text { Guidelines on administrative aspects }(1,2) \\
\text { Technical assistance }(1,2) \\
\text { Clarification of questions (2) } \\
\text { Declaration of expectations (2) }\end{array}$ \\
\hline $\begin{array}{l}\text { Affective (without } \\
\text { academic content) }\end{array}$ & $14.3 \%(1)$ & $\begin{array}{l}\text { Positive or encouraging remarks (1) } \\
\text { Acknowledging learner participation (1) } \\
\text { Providing affective support (1) } \\
\text { Apology (1) } \\
\text { Pro-social behaviour (1) }\end{array}$ \\
\hline $\begin{array}{l}\text { Feedback (with academic } \\
\text { content) }\end{array}$ & $\begin{array}{l}27.9 \%(1) \\
51.3 \%(2 \mathrm{a}) \\
10.7 \%(2 \mathrm{~b})\end{array}$ & $\begin{array}{l}\text { Supportive/corrective feedback }(1,2) \\
\text { Expanded feedback; providing feedback with } \\
\quad \text { example }(1,2) \\
\text { Weekly summaries (1) } \\
\text { Periodic intervention to direct and extend } \\
\quad \text { discussion (2) }\end{array}$ \\
\hline $\begin{array}{l}\text { Promoting deep learning } \\
\text { (with academic content) }\end{array}$ & $\begin{array}{c}10.3 \%(1) \\
4.2 \%(2 \mathrm{a}) \\
19.6 \%(2 \mathrm{~b})\end{array}$ & $\begin{array}{l}\text { Through reflective/Socratic questions }(1,2) \\
\text { Through hints (2) }\end{array}$ \\
\hline $\begin{array}{l}\text { Direct answering of } \\
\text { content questions (with } \\
\text { academic content) }\end{array}$ & $\begin{array}{l}9.7 \%(2 \mathrm{a}) \\
50 \%(2 \mathrm{~b})\end{array}$ & Providing direct answers (2) \\
\hline
\end{tabular}

* 1. Blignaut \& Trollip (2003), 2. Nandi, Hamilton, \& Harland (2012), 2a. Nandi et al. (2012): course Intro to IT, 2b. Nandi et al. (2012): course Intro to programming

Table 2 shows two marked differences between the findings of the two research projects: the affective role and direct instruction. Only Blignaut and Trollip (2003) reported affective behaviours, and direct answers were only identified in the research of Nandi et al. (2010). One possible explanation for these differences is the difference in discipline. Computer programming courses (Nandi et al., 2012) may ask for different behaviour than the business and education courses of Blignaut and Trollip (2003). Another possible explanation is that the one teacher that Nandi et al. (2012) followed was not inclined towards online affective behaviour and more towards providing direct answers. The 18 instructors in Blignaut and Trollip’s (2003) study showed large variations in inclination towards online affective behaviour. One of their business teachers scored zero affective messages, whereas the others show large variations in numbers of affective messages with a maximum of 62 messages for an education teacher. This is in line with the overall large variations in teacher behaviour in Blignaut and Trollip's (2003) study and it shows the importance of researching a number of online teachers and not just one.

Besides the behavioural analysis of online messages another research angle on teaching behaviour is: what kind of teacher behaviour do online students say they want from their online teachers? Several researchers pursued this question in interviews and/or surveys with students (Blignaut \& Trollip, 2003; Dennen, Darabi, \& Smith, 2007; Ke, 2010). Table 3 provides information on these studies. 
Table 3

Information on the three research projects

\begin{tabular}{|c|c|c|c|}
\hline $\begin{array}{c}\text { Authors, year of } \\
\text { publication }\end{array}$ & Research context & $\begin{array}{c}\text { Number of } \\
\text { students }\end{array}$ & Research instrument \\
\hline Blignaut \& Trollip (2003) & $\begin{array}{l}9 \text { graduate-level courses in } \\
\text { Business /Education }\end{array}$ & 3 & Interview \\
\hline Dennen et al. (2007) & $\begin{array}{l}\text { Mostly graduate-level courses } \\
\text { (94.1\%), numbers and subjects } \\
\text { not reported }\end{array}$ & 170 & Survey \\
\hline Ke (2010) & $\begin{array}{l}10 \text { courses ranging from } \\
\text { undergraduate to doctor's level } \\
\text { in Business/Education/Nursing }\end{array}$ & 16 & $\begin{array}{l}\text { Interviews: midterm and } \\
\text { end of term }\end{array}$ \\
\hline
\end{tabular}

Table 4 lists asynchronous behaviours that are valued by the majority of students in the study (> 60\% was used as a cut-off when percentages were reported), clustered in teaching roles that match the behavioural descriptions.

Table 4

Teacher behaviours preferred by students

\begin{tabular}{ll}
\hline Teacher role & Teacher behaviour \\
& Reported in research project(s)* \\
\hline Responsive & Post frequently to discussion forum/high online presence (2, 3) \\
& Prompt reactions (1, 2) \\
& Timeliness of feedback (2, 3) \\
& Acknowledging learner participation/Fair attention to each students' \\
& posts (1, 3) \\
Administrative & Guidelines on administrative aspects (1) \\
& Technical assistance (1, 2) \\
& Clearly communicate expectations through examples (2) \\
& Respond to student inquiries (2) \\
& Communicate rules and expectations (2) \\
& Address non-productive behaviour (2) \\
& Individual monitoring (2, 3) \\
& Individual support (3) \\
& Positive or encouraging remarks (1) \\
& Providing affective support (1) \\
Affective (without academic content) & Apology (1) \\
& Pro-social behaviour/ high social presence (1,3) \\
& Self-disclosure (3) \\
& Respond to emotional tones (2) \\
Feedback (with academic content) & Supportive feedback, rich in content (1,3) \\
Corrective feedback (1) \\
Weekly summaries, wrap-up postings (1) \\
Address individual needs (2) \\
Skilfully orchestrate discussions (3) \\
\hline
\end{tabular}

* 1. Blignaut \& Trollip (2003), 2. Dennen et al. (2007), 3. Ke (2010)

Table 4 lists teacher behaviours that may contribute to student satisfaction. The students in these research projects stated they prefer teacher behaviours that are classified as responsive, administrative, affective and feedback. They did not mention the behaviours in relation to promoting deep learning and direct answering of content questions that were identified in Table 2. Responsiveness is present in Table 4, but absent from Table 2 as most aspects of it cannot directly be addressed in this type of content analysis. The question remains as to 
the relations between actual teaching behaviour and student satisfaction. Does what students say they want their teachers to do really influence their satisfaction with online teaching?

\section{Methodology}

\section{Participants}

Eleven female instructors participated in the study. They agreed to the analysis of their messages. Six of these teachers were in their first year of online teaching. The other five teachers had 2-5 years of online teaching experience in the MSEN. All teachers were informed about the design principles of the online MSEN. Online teachers meet several times per year in order to discuss their teaching and the quality of their messages. When necessary, beginning online teachers obtain limited individual help crafting their online messages. The 11 instructors each taught one or two small groups of 3-8 students in eight different courses. All students were certified and experienced teachers or speech therapists. The mean age of the students in the MSEN e-learning is 40 years with a standard deviation of 9 years.

\section{Data collection and Instruments}

In the study, two data sources were used: 265 asynchronous messages of the MSEN instructors and an online survey of their students in which they expressed their level of satisfaction with their teachers' work. The instructor messages were extracted from the teaching discussions in the online platform. No messages were used from the so-called café section that is used for socialising and off-topic subjects. When an instructor taught the same course at the same time in two groups, only the instructor messages in the first group were used. The instructor messages differed somewhat between two groups but showed the same tendencies in content, length, complexity and element use. On several occasions, the instructor copied messages literally from one group to the other. This made the analysis of Group 2 less worthwhile. We assumed that analysis of the messages in the first group would be representative for the instructors' behaviour in both groups.

The second data source was an online survey of the instructors' students. In this online survey, students expressed their level of satisfaction with their teachers' work. They responded to a moderation scale that consisted of four questions that were answered in a 5-point Likert scale. This scale proved to be reliable with a Cronbach's alpha of 0.85 . The students also rated their overall satisfaction with the teaching on a scale of $1-$ 10. A total of 73 students responded to the survey.

\section{Data analysis}

In order to unravel the different elements of teaching behaviour that were present in the 265 teacher messages, a three-stage content analysis was performed. In the first phase, the messages were inspected on the basis of a preliminary scoring guide that was continuously adapted when new elements were identified and when scoring proved too difficult. This preliminary scoring guide resulted from previous research (Smits \& Voogt, 2009) and was based on the work of Collison, Elbaum, Haavind, and Tinker (2000), on the taxonomy developed by Blignaut and Trollip (2003) and on inspection of teacher messages. The second phase consisted of selective coding of the messages. In this phase, codes were clustered and the infrequently occurring codes that could not be clustered were removed in order to simplify the scoring process. The resulting new scoring guide is shown in Table 5 with explanations and examples. The behavioural elements in this scoring guide are clustered in four overarching categories: content, listening and feedback, organisation and affective behaviour. 
Table 5

Behavioural clusters and elements: explanation and examples

\begin{tabular}{|c|c|c|}
\hline $\begin{array}{c}\text { Behavioural } \\
\text { elements }\end{array}$ & Explanation & Examples of messages \\
\hline
\end{tabular}

\begin{tabular}{|c|c|c|}
\hline \multicolumn{3}{|c|}{ Content } \\
\hline $\begin{array}{l}\text { 1. Elaborate } \\
\text { content }\end{array}$ & $\begin{array}{l}\text { The teacher supplies content relevant } \\
\text { to the course and the discussion. She } \\
\text { supports this with reasoning and/or } \\
\text { referral to literature and/or presents } \\
\text { examples/stories in relation to the } \\
\text { content. The teacher gives elaborate } \\
\text { answers to content questions. As such } \\
\text { the teacher models what is expected } \\
\text { from the students in terms of } \\
\text { elaboration }\end{array}$ & $\begin{array}{l}\text { 'The 3-Tier model is an interesting puzzle, don't } \\
\text { you think? The video fragments nicely illustrate } \\
\text { the different approaches in Tier 1. You can also } \\
\text { clearly see the effects on the engagement of the } \\
\text { whole group. In this phase of beginning reading } \\
\text { all students need instruction in order to learn to } \\
\text { read (Armbruster, Lehr, \& Osborn, 2003; } \\
\text { Boushey \& Moser, 2006).' }\end{array}$ \\
\hline $\begin{array}{l}\text { 2. Questions to } \\
\text { focus }\end{array}$ & $\begin{array}{l}\text { The teacher formulates questions that } \\
\text { are meant to focus the discussion } \\
\text { and/or to further/deepen learning. }\end{array}$ & $\begin{array}{l}\text { 'The educational needs of Eliza are clearly more } \\
\text { complex than Björns' educational needs. Who } \\
\text { wants to start off an expanded description?' } \\
\text { 'It is interesting to find out whether good } \\
\text { practices can be translated to structural policies. } \\
\text { Which possibilities do you see?' }\end{array}$ \\
\hline \multicolumn{3}{|c|}{ Listening and feedback } \\
\hline $\begin{array}{l}\text { 3. Neutral } \\
\text { acknowledgment }\end{array}$ & $\begin{array}{l}\text { The teacher shows that she has read } \\
\text { the message(s) of the student(s) by } \\
\text { repeating, summarising, rephrasing } \\
\text { and/or combining (parts of) a } \\
\text { message/messages in a neutral way. } \\
\text { No praise words are used. }\end{array}$ & $\begin{array}{l}\text { 'X [name of student] asserts that opinion } \\
\text { formation is a necessary element of an } \\
\text { anticipation guide according to the authors.' }\end{array}$ \\
\hline 4. Specific praise & $\begin{array}{l}\text { The teacher gives a compliment while } \\
\text { specifically explaining what the } \\
\text { praise is about. The message usually, } \\
\text { but not necessarily, includes a praise } \\
\text { word. The compliment relates to } \\
\text { content aspects. }\end{array}$ & $\begin{array}{l}\text { ' } \mathrm{X} \text { [name of student], that is a good idea as you } \\
\text { will gain effectiveness through this small } \\
\text { adjustment.' } \\
\text { 'Hello all, Your reactions to my post 'burning } \\
\text { questions' are magnificent. My question led you } \\
\text { to explain several views and to examine student } \\
\text { engagement. In combination with your lesson } \\
\text { plans, it becomes clear to me that you are } \\
\text { developing concepts of integrated language } \\
\text { teaching.' }\end{array}$ \\
\hline $\begin{array}{l}\text { 5. Discrepancy } \\
\text { feedback }\end{array}$ & $\begin{array}{l}\text { The teacher provides specific } \\
\text { feedback in case of a discrepancy } \\
\text { between current understanding and } \\
\text { content/skills that are the learning } \\
\text { goal (Hattie \& Timperley, 2007). }\end{array}$ & $\begin{array}{l}\text { 'Hi X [name of student], in the attachment you } \\
\text { will find my feedback on your video. [... ]. I am } \\
\text { convinced that you can use the feedback on the } \\
\text { intervention to enhance the effectiveness of your } \\
\text { session. Keep constantly in mind what your target } \\
\text { is: letter-sound knowledge and sounding out } \\
\text { simple words. Choose activities that maximise the } \\
\text { time on these tasks.' }\end{array}$ \\
\hline
\end{tabular}




\begin{tabular}{|c|c|c|}
\hline \multicolumn{3}{|c|}{ Organisation } \\
\hline \multirow{3}{*}{$\begin{array}{l}\text { 6. Addresses } \\
\text { group }\end{array}$} & The teacher addresses the whole & 'Hallo all' \\
\hline & group with her salutation, not one or & 'Hallo [all names]' \\
\hline & two individuals from the group. & 'Dear group' \\
\hline \multirow{6}{*}{$\begin{array}{l}\text { 7. Organising the } \\
\text { discussion }\end{array}$} & The teacher starts and/or finishes the & Starting (and monitoring): \\
\hline & $\begin{array}{l}\text { discussion and/or she monitors the } \\
\text { discussion and encourages } \\
\text { participation. This behaviour is not } \\
\text { primarily content related, but related }\end{array}$ & $\begin{array}{l}\text { 'Nice start of the discussion, I am looking forward } \\
\text { to the contributions of X and Y [names of } \\
\text { students].' }\end{array}$ \\
\hline & to student participation and planning & Monitoring: \\
\hline & in time. & $\begin{array}{l}\text { 'When I count your contributions to the } \\
\text { discussion, I see that X [name of student] needs to } \\
\text { post the third message in this discussion. X, can } \\
\text { you answer these questions?' }\end{array}$ \\
\hline & & Finishing (and monitoring): \\
\hline & & $\begin{array}{l}\text { 'After the contribution of X [name of student], we } \\
\text { will close the discussion.' }\end{array}$ \\
\hline \multirow{3}{*}{$\begin{array}{l}\text { 8. Organisational } \\
\text { and technological } \\
\text { support }\end{array}$} & The teacher explains the course & 'Hi X [name of student], of course, you may \\
\hline & $\begin{array}{l}\text { structure and/or assignments and/or } \\
\text { provides support for logistic aspects } \\
\text { of the course like dates, software, }\end{array}$ & $\begin{array}{l}\text { contribute one last message to this discussion. And } \\
\text { the others may do so too so you can reflect on } \\
\text { each other's messages.' }\end{array}$ \\
\hline & primarily content related. & $\begin{array}{l}\text { 'Hi all, I see that you have not yet opened a } \\
\text { collaborative TitanPad. I will help you with that so } \\
\text { that you can collect information from discussions } \\
\text { and feedback in the TitanPad and find support in } \\
\text { the literature.' }\end{array}$ \\
\hline
\end{tabular}
9. Non- specific
praise

10. Social behaviour

11. Expression of online personality
The teacher gives a superficial compliment without specifically explaining what the praise is about. The message usually, but not necessarily, includes a praise word. The teacher shows social behaviour towards students; she expresses friendliness, tact, personal interest and/or empathy and/or gives feedback on group dynamics/ collaboration. This behaviour is not primarily content related.

The teacher expresses online personality through disclosure of personal inspiration and emotions and through storytelling around personal experiences. This behaviour may or may not be content related.
'A nice discussion; keep up the good work.'

'So good to read that you collaborate in such a structured way. You stick to the assignment and you summarise along the way. My compliments to you all!'

'I want to thank X [name of student] for the constructive way she expresses her 'frustration', reading back in my own contributions I think I may unwillingly have contributed to this frustration.'

'It makes me really happy to read all your statements about the importance of reading motivation for all children, Elsa included!' 
In the third phase, the messages were analysed with the resulting new scoring guide (Table 5). The analysis was conducted on the message level. Per message, 11 behavioural elements could be scored. A particular element could only be scored once per message in order to optimise inter-scorer reliability and to reduce the complexity of the analysis. Part of the coding was done in collaboration and negotiation with a second rater in order to test the usability of the scoring guide and the inter-rater reliability. The scoring guide proved relatively easy to use for the second rater and not much discussion was needed. After the second phase, we calculated for each instructor which percentage of her messages contained each of the 11 elements. Comparisons of element use were made on the basis of these percentages. The 265 messages were also analysed by counting the number of messages per discussion, the number of words in each message, the number of words per sentence and the number of codes per message. Medians for these measures were calculated per teacher.

Per teacher means and standard deviations were calculated for the two measures for student satisfaction with online teacher behaviour: the moderation scale and the grade (1-10). The teachers were then divided into two groups, HS and LS, in order to identify differences in element use between the two groups. The LS group consisted of three inexperienced online teachers in their first year of online teaching, who scored below 7.0 on the scale of $1-10$. In the institution, a score below 7.0 on the 1-10 scale is seen as unacceptable, and a mean of 7.6 is the target for all teachers whether online or face-to-face. The HS group scored 7.6 or higher on the 110 scale. The HS group consisted of two inexperienced teachers in their first year of online teaching and four experienced online teachers with 2-5 years of online teaching experience. The two teachers who scored between 7.0 and 7.6 were excluded from further analysis because their score was neither unacceptable nor high.

Hierarchical clustering was used to identify whether the HS and LS group were characterised by groupspecific patterns of element use. The clustering was based on the percentages of instructor messages in which each of the 11 elements was identified. Between-groups linkage was calculated using the Chi-square measure. When two groups were entered, the outcomes of the hierarchical clustering process matched the student satisfaction scores. This means that the two groups that were identified HS and LS on the basis of survey scores were also differentiated on the basis of their patterns of element use.

After confirmatory hierarchical clustering, the differences between the element use, the number of messages and the complexity of the messages in the two groups were calculated by means of a Mann-Whitney U test. This test was chosen because of the small number of teachers in each group. The effect size was calculated on the basis of the Mann-Whitney U Z-statistic.

\section{Findings}

\section{Student satisfaction}

The students graded their satisfaction with their online teachers on a scale of 1-10 and filled out the moderation scale $(1=$ strongly disagree, $5=$ strongly agree). The correlation between the two measures proved highly significant, $r=0.96, p<0.001$. In Figure 1, the results are aggregated per teacher.

Figure 1 shows large differences between the teachers. Mean grades (1-10) fluctuated between 4.1 and 8.7, with a grade of 4.1 being markedly insufficient and 8.7 expressing great satisfaction. Three teachers scored unacceptably low as they scored below 7.0. On the moderation scale, the means lie between 1.9 and 4.8. Scores below 4 indicate that the students do not (fully) agree that the teacher has shown the different positive aspects of moderating behaviour that are listed in the survey. Only the five teachers with the highest grades ( $\geq$ 7.8) scored 4 or higher on the moderation scale. Three more teachers score acceptably above 3.5. One of these teachers belongs to the LS group. 


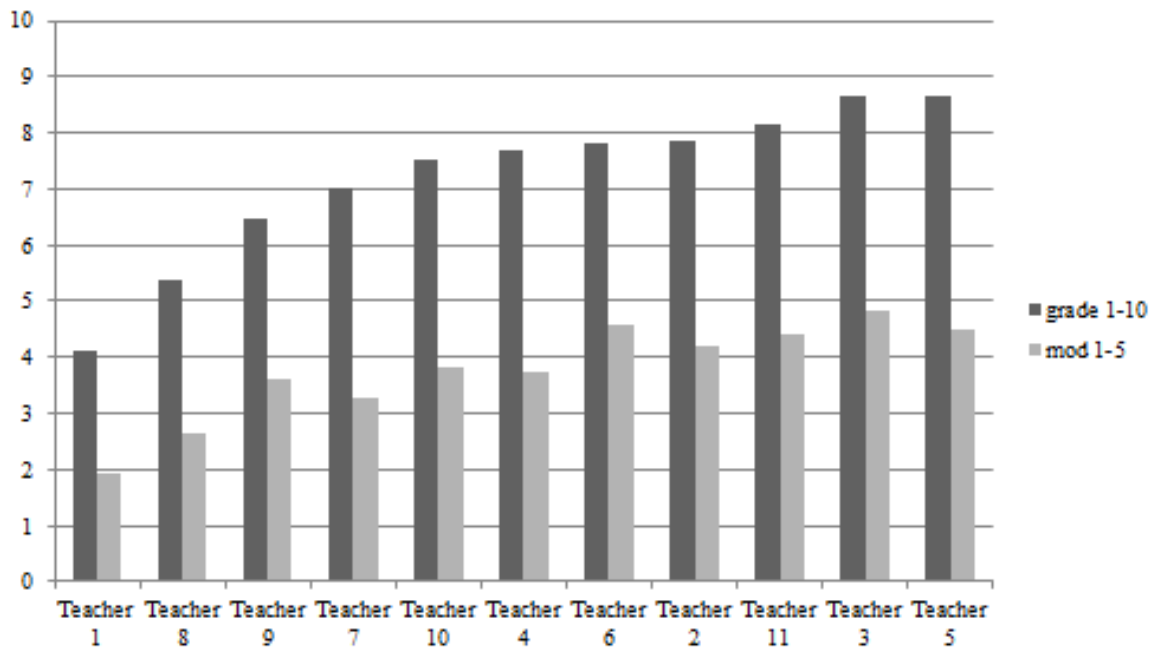

Figure 1. Student satisfaction for all teachers $(N=11)$

\section{Element use}

The 265 teacher messages were coded on the basis of the scoring guideline. Table 6 shows the 11 behavioural elements with minimum, maximum and median percentages of teacher messages that contain the specific element.

Table 6

Percentages of messages that contain specific elements $(N=11)$

\begin{tabular}{cc}
\hline Behavioural elements & $\begin{array}{c}\text { Min-Max percentage } \\
\text { of messages }\end{array}$
\end{tabular}

\section{Content}

Elaborate content

Questions to focus

Listening and feedback

Neutral acknowledgment

Specific praise

Discrepancy feedback

Addresses group

Organising the discussion

Organisational and technological support

\section{Social/emotional behaviour}

Nonspecific praise

Social behaviour

Organisation

$\begin{array}{ll}0-73 \% & 40 \% \\ 5-60 \% & 31 \%\end{array}$

Expression of online personality

$\begin{array}{cc}2-63 \% & 35 \% \\ 0-45 \% & 27 \% \\ 0-53 \% & 14 \% \\ & \\ 4-100 \% & 77 \% \\ 0-64 \% & 9 \% \\ 5-39 \% & 29 \%\end{array}$

$0-55 \% \quad 19 \%$

$0-30 \% \quad 12 \%$

$0-30 \% \quad 13 \%$

The column with minimum and maximum percentages shows large differences in the use of behavioural elements between teachers. Not all different elements were used by all teachers as can be inferred from the zeros in the column with minimum and maximum percentages. From the column with median percentages of messages, it can be concluded that most instructor messages address the group ( $M d n=77 \%$ ) as opposed to the individual. Other highly frequent elements $(M d n \geq 25 \%)$ are elaborate content, neutral acknowledgment, questions to focus, organisational support and specific praise. These most frequent elements belong to three 
clusters from Table 6: content, listening/feedback and organisation. Behaviours in the fourth cluster (social/emotional behaviour) are less frequently observed in the teaching discussions.

\section{Groups (HS and LS) and element use}

The Mann-Whitney U test was used to calculate whether the two groups (HS and LS) differed significantly in their use of the different behavioural elements. The results and effect sizes ( $r$ ) are shown in Table 7.

Table 7

HS-LS Differences in element use

\begin{tabular}{|c|c|c|c|c|c|c|}
\hline $\begin{array}{l}\text { Behavioural } \\
\text { elements }\end{array}$ & $\begin{array}{c}\text { Mdn (Min- } \\
\text { Max) } \\
\text { percentages of } \\
\text { messages } \\
\text { HS } \\
N=6 \\
\end{array}$ & $\begin{array}{c}\text { Mdn (Min- } \\
\text { Max) } \\
\text { Percentages of } \\
\text { messages } \\
\text { LS } \\
N=3 \\
\end{array}$ & $\begin{array}{c}\text { Mann } \\
\text {-Whitney } \\
U\end{array}$ & $Z$ & $\begin{array}{c}\text { Exact } \\
\text { significance }\end{array}$ & $\begin{array}{l}\text { Effect } \\
\text { size } r\end{array}$ \\
\hline Addresses group & $87 \%(53-100)$ & $5 \%(4-13)$ & 0.000 & 2.324 & $0.024^{*}$ & 0.77 \\
\hline Elaborate content & $42 \%(35-73)$ & $13 \%(0-14)$ & 0.000 & 2.324 & $0.024 *$ & 0.77 \\
\hline $\begin{array}{l}\text { Neutral } \\
\text { acknowledgment }\end{array}$ & $37 \%(19-60)$ & $13 \%(2-13)$ & 0.000 & 2.324 & $0.024 *$ & 0.77 \\
\hline Questions to focus & $32 \%(18-60)$ & $9 \%(5-38)$ & 4.000 & 1.291 & 0.262 & 0.43 \\
\hline Specific praise & $38 \%(21-45)$ & $2 \%(0-13)$ & 0.000 & 2.324 & $0.024^{*}$ & 0.77 \\
\hline $\begin{array}{l}\text { Organisational } \\
\text { support }\end{array}$ & $19 \%(7-39)$ & $38 \%(5-39)$ & 7.000 & 0.516 & 0.714 & 0.17 \\
\hline Nonspecific praise & $21 \%(4-55)$ & $8 \%(0-22)$ & 4.000 & 1.291 & 0.262 & 0.43 \\
\hline $\begin{array}{l}\text { Organising the } \\
\text { discussion }\end{array}$ & $14 \%(0-64)$ & $9 \%(3-13)$ & 6.000 & 0.775 & 0.548 & 0.26 \\
\hline Discrepancy feedback & $8 \%(0-21)$ & $17 \%(13-17)$ & 4.000 & 1.296 & 0.262 & 0.43 \\
\hline Social behaviour & $16 \%(7-30)$ & $5 \%(0-9)$ & 2.000 & 1.807 & 0.095 & 0.60 \\
\hline Emotion/personality & $17 \%(8-30)$ & $0 \%(0-9)$ & 1.000 & 2.074 & $0.048 *$ & 0.69 \\
\hline
\end{tabular}

* Statistically significant $p<0,05$

The HS group made significantly more use of the five following elements compared to the LS group: addresses group, elaborate content, neutral acknowledgement, specific praise and emotion/personality. The effect sizes for all these differences were high $(r>0.5)$. For the other elements, no significant differences were found between the HS and the LS group.

\section{The number of messages per discussion}

In asynchronous e-learning, attendance of the teacher can be operationalised through the number of messages that the teacher crafts per teaching discussion. In the e-learning design under study, the discussions had a duration of 1.5 weeks. Table 8 shows the number of messages per discussion for the HS and LS groups.

Table 8

Number of messages per discussion

\begin{tabular}{lllll}
\hline Group & $\boldsymbol{N}$ & Minimum & Maximum & Median \\
\hline HS & 6 & 2.20 & 5.17 & 4.33 \\
LS & 3 & 2.00 & 7.11 & 2.09 \\
\hline
\end{tabular}

A Mann-Whitney U test was used to compare the HS and LS groups. No significant differences were identified $(U=6, p=0.439, r=0.26)$. The median number of messages shows that, in most cases, the attendance requirements (i.e., three contributions per discussion) were met by the HS teachers but not by the LS teachers. The minimum values show that, even in the HS group, not all teachers met the minimum 
requirements. The number of messages per discussion is much smaller than the mean of 10.38 messages per discussion in Blignaut and Trollip's (2003) study (see Table 1). This could be explained by the fact that the student groups in their study were larger $(X=15.2)$ than in the current study (5-8 students per group). In addition, the teachers in Blignaut and Trollip's (2003) study often reacted to individual postings, whereas teachers in the current study were often seen to address the whole group, weaving their reactions to several student postings in one message.

\section{Complexity of the messages}

The complexity of the messages was calculated in three ways: the mean number of words per message, the mean number of different behavioural elements per message and the mean sentence length. The MannWhitney $\mathrm{U}$ test was used to calculate differences between the HS and LS groups. The results are depicted in Table 9.

Table 9

\begin{tabular}{|c|c|c|c|c|c|c|}
\hline Complexity & $\begin{array}{c}\text { Mdn } \\
\text { (Min-Max) } \\
\text { HS } \\
\text { N=8 }\end{array}$ & $\begin{array}{c}\text { Mdn } \\
\text { (Min-Max) } \\
\text { LS } \\
\text { N=3 }\end{array}$ & $\begin{array}{c}\text { Mann- } \\
\text { Whitney } \\
U\end{array}$ & $Z$ & $\begin{array}{c}\text { Exact } \\
\text { significance }\end{array}$ & $\begin{array}{l}\text { Effect } \\
\text { size } r\end{array}$ \\
\hline $\begin{array}{l}\text { Number of words per } \\
\text { message }\end{array}$ & $\begin{array}{c}161.80 \\
(137-191)\end{array}$ & $\begin{array}{c}41.11 \\
(37-57)\end{array}$ & .000 & 2.324 & $0.024 *$ & 0.77 \\
\hline $\begin{array}{l}\text { Number of behavioural } \\
\text { elements per message }\end{array}$ & $\begin{array}{c}3.66 \\
(2.83-4.0)\end{array}$ & $\begin{array}{c}1.38 \\
(0.64-1.43)\end{array}$ & .000 & 2.324 & $0.024^{*}$ & 0.77 \\
\hline $\begin{array}{l}\text { Number of words per } \\
\text { sentence }\end{array}$ & $\begin{array}{c}16.70 \\
(14.2-20.7)\end{array}$ & $\begin{array}{c}14.20 \\
(10.9-20.7)\end{array}$ & 1.500 & 1.945 & $0.048^{*}$ & 0.65 \\
\hline
\end{tabular}

* Statistically significant $p<0.05$

A large difference is shown in the number of words per message: the HS group used significantly more words per message than the LS group. The HS group also crafted significantly more complex messages in terms of the number of behavioural elements. The HS group crafted significantly longer sentences than the LS group. All effect sizes were large $(r>0.5)$.

\section{Conclusions}

The qualitative and quantitative data analysis show that the pedagogical behaviour of the HS teacher group differs from that of the LS group. Teachers in the HS group, mostly, but not exclusively, address the whole group as opposed to the individual student. The content of their messages shows careful listening to the individual students as they acknowledge individual contributions and provide specific positive feedback. The HS teachers write elaborate postings that show their knowledge and thinking about the subject in reaction to the student messages. HS teachers show online personality and social behaviour in some, but not all, asynchronous messages. Both HS and LS teachers contributed at least twice per 1.5 weekly discussions. No differences in the frequency of attendance were found between the two groups. Large differences were found with respect to the length and the pedagogical complexity of the messages. The HS group wrote more words per message, crafted longer sentences, and their messages contained more behavioural elements than the messages of the LS group. The answer to what constitutes an effective asynchronous online teacher does not lie in any single behavioural element, but in elaborate combinations of them. All elements in the instrument seem to be valuable aspects of online teaching, but HS teachers stand out through their way of addressing the group with an intricate weaving of listening, specific positive feedback, elaborate subject knowledge and online personality in their messages. 


\section{Discussion}

This study provides an answer to a part of the fundamental question posed by Blignaut and Trollip (2003): how do different teaching behaviours relate to student learning outcomes and satisfaction? Leaving out the question of learning outcomes, this study suggests the importance of the following behavioural components for student satisfaction: addressing the group, neutral acknowledgement, specific praise, elaborate content and online personality. This answer contributes to the discussion that was started by Bawane and Spector (2009) about prioritisation of online instructor roles in competency-based teacher education programs. This is an important discussion as the prioritisation of online instructor roles has financial and practical implications for institutions that provide online teacher training as well as their online teachers.

Employing a survey for experts, Bawane and Spector (2009) asserted the following order of importance for the five most important online teaching roles: (1) pedagogical, (2) professional, (3) evaluator, (4) social, (5) technologist. In their comprehensive list of eight teaching roles, Bawane and Spector (2009) tried to capture all that is going on in online teaching, including the design of the online teaching materials. Hence, their categories are rather broad and do not correspond well to the finesses of HS asynchronous messages in teaching discussion. It is certainly possible to categorise the aspects of HS behaviour that we found as pedagogical, evaluator and social, but the behaviours that we found do not match the Bawane and Spector's (2009) description of these categories.

Noteworthy is the difficulty to categorise elaboration on content in Bawane and Spector's (2009) teaching roles. Unlike Koehler and Mishra (2008) in their technological, pedagogical, content knowledge framework (TPACK), Bawane and Spector do not specifically mention content knowledge as an essential part of online teaching. Our findings confirm that content knowledge is a cornerstone of online teaching and emphasise the need for content specialists as online teachers. The content specialist adds relevant content to the student discussion and facilitates the acquisition of difficult content. This counters the belief that online moderators should move away from the centre of the learning process and be a guide on the side or a ghost in the wings. The findings corroborate earlier findings on the importance of active online teacher behaviour for student satisfaction and learning (Arbaugh, 2010; Bangert, 2008; Ke, 2010; Marks et al., 2005; Pawan, Paulus, Yalcin, \& Chang, 2003).

In line with the literature, the current study shows large differences between teachers' online behaviour (Blignaut \& Trollip, 2003; Morris et al., 2005). These large differences in teacher behaviour in the past often lead to serial reporting of scores on the individual teacher level and to difficulties in showing patterns of behaviours. In the current study, the grouping of teachers on the basis of satisfaction scores and hierarchical clustering facilitated uncovering characteristics of more and less satisfactory online teaching. In the current research, some specific markers were uncovered that may signal successful online teaching. Some of these markers are qualitative in nature (e.g., addresses group, elaborative content) and others are quantitative (e.g., behavioural complexity, length of postings).

It could be argued that elaborate complex asynchronous messages aggravate the workload of online teachers. An interesting marker, however, is addresses group. In many accounts of online teachers, there is much individual communication between teachers and students going back and forth (e.g., Davidson-Shivers, 2009). In the original design, we tried to minimise the individual communication and individual assignments and to maximise asynchronous group communication within the groups of 5-8 students. Teachers typically teach two of these groups. From the current study, it can be inferred that students value the fact that teacher communication is directed to the group. So, on the one hand, the workload increases because of the high quality and the length of the messages that need to be produced but, on the other hand, the workload is reduced through minimisation of individual communication and assignments.

It takes time and effort to teach online. Successful online teachers work hard to write elaborate postings in which they listen to students and share their knowledge. Students value this kind of complex teaching 
behaviour. Institutions should grant their employees ample time for this task and time and opportunities to learn and improve as online teachers.

\section{Limitations and future research}

In this research, only the teaching discussions were investigated and not the asynchronous postings in the café. The café in the design under investigation is the place where so-called off-topic talk takes place. In the café, there is more room for social interaction and organisational support than in teaching discussions. The distribution of behavioural elements in café discussions will be different from teaching discussions. Most likely, student satisfaction with the online teacher will also be influenced by the interaction with the teacher in the café. Analysis of the teacher role in the café, therefore, seems an interesting research topic for the future. For this analysis, adaptation of the scoring guideline may be necessary because of the different character of the discussions.

This study set out to uncover behavioural differences between HS and LS teachers in asynchronous discussions. Now that several characteristic behavioural differences between HS and LS online teachers were identified, the next level of interest is the question into the origins of these differences. Promising candidates for these origins seem the level of content knowledge and the teachers' epistemic and pedagogical beliefs (Kim, Kim, Lee, Spector, \& DeMeester, 2013). Questions that arise are:

- $\quad$ Are the HS behavioural patterns associated with being more knowledgeable in the subject of the course?

- $\quad$ Are the HS behavioural patterns associated with specific epistemic and pedagogical beliefs?

These questions are important in the light of the ongoing discussion on the depth and the nature of the online teachers' role and the activities and the consequences thereof for task assignment, workload and compensation within higher education institutions.

The present analysis concerns a one-sided analysis of the teacher messages. On the basis of this analysis, questions arise about the fit between the student and teacher messages. How carefully does the teacher listen to the students? Are there any misunderstandings? Does the teacher use what students are saying in order to bring in knowledge to advance their understanding of the subject? And are there differences between HS and LS teachers in the answers to these questions?

The construction of a scoring guideline requires a delicate balance. When it contains too many categories, scoring becomes difficult, time-consuming and unreliable (Blignaut \& Trollip, 2003). When it contains too few categories, scoring misses depth and differentiation. This leads to information loss. In the current guideline, infrequently scored elements were omitted or collapsed into other elements. The possibility exists that potentially interesting categories were lost. A potentially interesting category that was lost was progress feedback, where the teacher mentions in which respects the students make progress in their learning. This category was only scored once in the entire sample and was collapsed into the element specific praise. In our institution, we will use the scoring guide to monitor the teachers' messages and to help them to further improve their asynchronous online teaching while keeping an open eye for new categories that may be needed in the future.

\section{References}

Abdous, M. (2010). A process-oriented framework for acquiring online teaching competencies. Journal of Computing in Higher Education, 23(1), 60-77. doi:10.1007/s12528-010-9040-5

Anderson, T., Rourke, L., Garrison, D. R., \& Archer, W. (2001). Assessing teaching presence in a computer conferencing context. JALN, 5(2), 1-17. Retrieved from http://auspace.athabascau.ca/handle/2149/725

Arbaugh, J. B. (2001). How instructor immediacy behaviors affect student satisfaction and learning in webbased courses. Business Communication Quarterly, 64(4), 42-54. doi:10.1177/108056990106400405 
Arbaugh, J. B. (2010). Sage, guide, both, or even more? An examination of instructor activity in online MBA courses. Computers \& Education, 55(3), 1234-1244. doi:10.1016/j.compedu.2010.05.020

Arbaugh, J. B. (2014). System, scholar or students? Which most influences online MBA course effectiveness? Journal of Computer Assisted Learning, 30(4), 349-362. doi:10.1111/jcal.12048

Arbaugh, J. B., \& Hwang, A. (2006). Does "teaching presence" exist in online MBA courses? The Internet and Higher Education, 9(1), 9-21. doi:10.1016/j.iheduc.2005.12.001

Bangert, A. (2008). The influence of social presence and teaching presence on the quality of online critical inquiry. Journal of Computing in Higher Education, 20(1), 34-61. doi:10.1007/BF03033431

Baran, E., Correia, A.-P., \& Thompson, A. (2011). Transforming online teaching practice: Critical analysis of the literature on the roles and competencies of online teachers. Distance Education, 32(3), 421-439. doi:10.1080/01587919.2011.610293

Baran, E., Correia, A.-P., \& Thompson, A. D. (2013). Tracing successful online teaching in higher education: Voices of exemplary online teachers. Teachers College Record, 115(3), 1-41.

Bawane, J., \& Spector, J. M. (2009). Prioritization of online instructor roles: implications for competencybased teacher education programs. Distance Education, 30(3), 383-397. doi:10.1080/01587910903236536

Blignaut, S., \& Trollip, S. R. (2003). Developing a taxonomy of faculty participation in asynchronous learning environments—an exploratory investigation. Computers \& Education, 41(2), 149-172. doi:10.1016/S0360-1315(03)00033-2

Bolliger, D. U., \& Wasilik, O. (2009). Factors influencing faculty satisfaction with online teaching and learning in higher education. Distance Education, 30(1), 103-116. doi:10.1080/01587910902845949

Brower, H. H. (2003). On emulating classroom discussion in a distance-delivered OBHR course: Creating an on-line learning community. Academy of Management Learning \& Education, 2(1), 22-36. doi:10.5465/AMLE.2003.9324013

Collison, G., Elbaum, B., Haavind, S., \& Tinker, R. (2000). Facilitating online learning. Effective strategies for moderators. Madison, WI: Atwood Publishing.

Conceição, S. C. (2006). Faculty lived experiences in the online environment. Adult Education Quarterly, 57(1), 26-45. doi:10.1177/1059601106292247

Conrad, D. (2004). University instructors' reflections on their first online teaching experiences. Journal of Asynchronous Learning Network, 8(2), 31-44. doi:10.1.1.110.1754

Conrad, D. (2005). Building and maintaining community in cohort-based online learning. Journal of Distance Education, 20(1), 1-20. Retrieved from ERIC database. (EJ807822)

Coppola, N. W., Hiltz, S. R., \& Rotter, N. G. (2002). Becoming a virtual professor: Pedagogical roles and asynchronous learning networks. Journal of Management Information Systems, 18(4), 169-189. doi:10.1080/07421222.2002.11045703

Davidson-Shivers, G. V. (2009). Frequency and types of instructor-interactions in online instruction. Journal of Interactive Online Learning, 8(1), 23-40. Retrieved from http://www.ncolr.org/jiol/issues/pdf/8.1.2.pdf

Dennen, V. P., Darabi, A., \& Smith, L. J. (2007). Instructor-learner interaction in online courses: The relative perceived importance of particular instructor actions on performance and satisfaction. Distance Education, 28(1), 65-79. doi:10.1080/01587910701305319

Dunlap, J. C. (2005). Workload reduction in online courses: Getting some shuteye. Performance Improvement, 44(5), 18-25. doi:10.1002/pfi.4140440507

Easton, S. S. (2003). Clarifying the instructor's role in online distance learning. Communication Education, 52(2), 87-105. doi:10.1080/03634520302470

Faber, A., \& Mazlish, E. (1996). How to talk so kids can learn. At home and in school. London: Piccadilly Press.

Ferdig, R. E., \& Roehler, L. R. (2004). Student uptake in electronic discussions: Examining online discourse in literacy pre-service classrooms. Journal of Research on Technology in Education, 36, 119-136. doi:10.1080/15391523.2003.10782408

Garrison, D. R., Anderson, T., \& Archer, W. (2000). Critical inquiry in a text-based environment: Computer conferencing in higher education. The Internet and Higher Education, 2(2-3), 87-105. doi:10.1016/S1096$\underline{7516(00) 00016-6}$

Hattie, J., \& Timperley, H. (2007). The power of feedback. Review of Educational Research, 77(1), 81-112. doi:10.3102/003465430298487 
Hewitt, J. (2005). Toward an understanding of how threads die in asynchronous computer conferences. Journal of the Learning Sciences, 14(4), 567-589. doi:10.1207/s15327809jls1404_4

Huang, X., \& Hsiao, E.L. (2012). Synchronous and asynchronous communication in an online environment: Faculty experiences and perceptions. Quarterly Review of Distance Education, 13(812), 15-30. Retrieved from ERIC database. (EJ1005835)

Ke, F. (2010). Examining online teaching, cognitive, and social presence for adult students. Computers and Education, 55(2), 808-820. doi:10.1016/j.compedu.2010.03.013

Kim, C., Kim, M. K., Lee, C., Spector, J. M., \& DeMeester, K. (2013). Teacher beliefs and technology integration. Teaching and Teacher Education, 29(1), 76-85. doi:10.1016/j.tate.2012.08.005

Koehler M., \& Mishra P. (2008). Introducing TPCK. In AACTE Committee on Innovation and Technology (Eds.), Handbook of technological pedagogical content knowledge (TPCK) for educators (pp. 3-29). New York, NY: Routledge.

Kreijns, K. (2004). Sociable CSCL environments. Social affordances, sociability, and social presence (Doctoral dissertation). Open Universiteit, Heerlen, the Netherlands. Retrieved from http://dspace.learningnetworks.org/bitstream/1820/1030/1/Dissertation Kreijns\%2 02004.pdf

Lee, Y., \& Choi, J. (2010). A review of online course dropout research: Implications for practice and future research. Educational Technology Research and Development, 59(5), 593-618. doi:10.1007/s11423-010$\underline{9177-\mathrm{y}}$

Levy, Y. (2007). Comparing dropouts and persistence in e-learning courses. Computers \& Education, 48(2), 185-204. doi:10.1016/j.compedu.2004.12.004

Marks, R. B., Sibley, S. D., \& Arbaugh, J. B. (2005). A structural equation model of predictors for effective online learning. Journal of Management Education, 29(4), 531-563. doi:10.1177/1052562904271199

Mazzolini, M., \& Maddison, S. (2003). Sage, guide or ghost? The effect of instructor intervention on student participation in online discussion forums. Computers \& Education, 40(3), 237-253. doi:10.1016/S03601315(02)00129-X

Morris, L. V., Xu, H., \& Finnegan, C. L. (2005). Roles of faculty in teaching asynchronous undergraduate courses. Journal of Asynchronous Learning Networks, 9(1), 65-82. Retrieved from http://olc.onlinelearningconsortium.org/sites/default/files/v9n1_morris_1.pdf

Mullen, G. E., \& Tallent-Runnels, M. K. (2006). Student outcomes and perceptions of instructors' demands and support in online and traditional classrooms. The Internet and Higher Education, 9(4), 257-266. doi:10.1016/j.iheduc.2006.08.005

Nandi, D., Hamilton, M., \& Harland, J. (2012). Evaluating the quality of interaction in asynchronous discussion forums in fully online courses. Distance Education, 33(1), 5-30. doi:10.1080/01587919.2012.667957

Nicol, D. J., \& Milligan, C. (2006). Rethinking technology-supported assessment in terms of the seven principles of good feedback practice. In C. Bryan and K. Clegg (Eds.), Innovative assessment in higher education (pp. 64-78). London, UK: Taylor and Francis Group.

Pallof, R., \& Pratt, K. (2003). The virtual student. San Francisco, CA: Jossey-Bass.

Pawan, F., Paulus, T. M., Yalcin, S., \& Chang, C. (2003). Online learning: Patterns of engagement and interaction among in-service teachers. Language Learning \& Technology, 7(3), 119-140. Retrieved from http://ltt.msu.edu/vol7num3/pdf/pawan.pdf

Reilly, J. R., Vandenhouten, C., Gallagher-Lepak, S., \& Ralston-Berg, P. (2012). Faculty development for elearning: A multi-campus community of practice (COP) approach. Journal of Asynchronous Learning Network, 16(2), 99-110. Retrieved from ERIC database. (EJ971047)

Roblyer, M. D., \& Wiencke, W. R. (2003). Design and use of a rubric to assess and encourage interactive qualities in distance courses. The American Journal of Distance Education, 17(2), 77-98. doi:10.1207/S15389286AJDE1702_2

Rourke, L., \& Anderson, B. (2002). Using peer teaching to lead online discussions. Journal of Interactive Media in Education, 7(1), 112-120. Retrieved from http://jime.open.ac.uk/articles/10.5334/2002-1/

Rourke, L., Anderson, T., Garrison, D. R., \& Archer, W. (1999). Assessing social presence in asynchronous text-based computer conferencing. Journal of Distance Education, 14(2), 50-71. Retrieved from http://www.ijede.ca/index.php/jde/article/view/153/341

Rourke, L., \& Kanuka, H. (2009). Learning in communities of inquiry: A review of the literature. Journal of Distance Education, 23(1), 19-48. Retrieved from http://ijede.ca/index.php/jde/article/view/474/875 
Savery, J. R. (2005). Be vocal: Characteristics of successful online instructors. Journal of Interactive Online Learning, 4(2), 141-152. Retrieved from http://www.ncolr.org/issues/jiol/v4/n2/be-vocal-characteristicsof-successful-online-instructors

Shattuck, J., \& Anderson, T. (2013). Using a design-based research study to identify principles for training instructors to teach online. International Review of Research in Open and Distance Learning, 14(5), 186210. Retrieved from http://www.irrodl.org/index.php/irrodl/article/view/1626

Shea, P. (2007). Bridges and barriers to teaching online college courses: a study of experienced online faculty in thirty-six colleges. Journal of Asynchronous Learning Networks, 11(2), 73-128. Retrieved from http://onlinelearningconsortium.org/jaln_article/bridges-and-barriers-to-teaching-online-college-courses-astudy-of-experienced-online-faculty-in-thirty-six-colleges-2/

Shea, P., Hayes, S., Uzuner-Smith, S., Gozza-Cohen, M., Vickers, J., \& Bidjerano, T. (2014). Reconceptualizing the community of inquiry framework: An exploratory analysis. Internet and Higher Education, 23, 9-17. doi:10.1016/j.iheduc.2014.05.002

Sher, A. (2009). Assessing the relationship of student-instructor and student-student interaction to student learning and satisfaction in web-based online learning environment. Journal of Interactive Online Learning, 8(2), 102-120. Retrieved from http://www.ncolr.org/jiol/issues/pdf/8.2.1.pdf

Smits, A. E. H. (2012). Ontwerp en implementatie van de masteropleiding [Special Educational Needs via elearning]. Dissertatie. Enschede: Universiteit Twente. Retrieved from http://doc.utwente.nl/82586/

Smits, A. E. H. \& Voogt, J. M. (2009). Elements of online teacher behaviour that lead to student satisfaction. Proceedings of ICDE 2009. Maastricht: Open Universiteit. Retrieved from https://www.researchgate.net/publication/237815185_ELEMENTS_OF_ONLINE_TEACHER_BEHAVI OUR_THAT_LEAD_TO_STUDENT_SATISFACTION

Smits, A. E. H., Voogt, J. M., \& van den Akker, J. J. H. (2013). Design and development of an online version of a special educational needs master's program. In T. Plomp \& N. Nieveen (Eds.), Educational design research - Part B: Illustrative cases (pp. 799-826). Enschede: S.L.O. Retrieved from http://international.slo.nl/publications/edr/contents/c38/

Spector, J. M. (2005). Time demands in online instruction. Distance Education, 26(1), 5-27. doi:10.1080/01587910500081251

Stein, D. S., Wanstreet, C. E., Calvin, J., Overtoom, C., \& Wheaton, J. E. (2005). Bridging the transactional distance gap in online learning environments. American Journal of Distance Education, 19(2), 105-118. doi:10.1207/s15389286ajde1902_4

Corresponding author: Anneke Smits, aeh.smits@windesheim.nl

Australasian Journal of Educational Technology @ 2017.

Please cite as: Smits, A., \& Voogt, J. (2017). Elements of satisfactory online asynchronous teacher behaviour in higher education. Australasian Journal of Educational Technology, 33(2), 97-114. https://doi.org/10.14742/ajet.2929 